\title{
Analisis Epitope Sel T pada SARS-Cov2 dengan Pendekatan Bioinformatika
}

\section{(Analysis of T-cell Epitopes of SARS-Cov2 with Bioinformatics Approach)}

\author{
Miftahurrahma Rosyda $^{1 *}$, Faisal Fajri Rahani ${ }^{2}$
}

\begin{abstract}
At the beginning of 2020, the world was shocked by the spread of global outbreaks that attacked respiratory like the SARS outbreak in 2003, namely COVID-19. The virus that causes the outbreak called SARS-Cov2. It turns out to have a similarity of $\sim 87.5 \%$ with SARS-Cov. This similarity can be used to develop drugs and vaccines that are compatible with the current virus. In this case, the bioinformatics approach can be carried out as an initial stage of vaccine development. One way to develop vaccines is epitope-based vaccines. Biological data available and submitted to the public regarding $T$ cell epitopes and protein sequences in viruses can be processed with several bioinformatics tools available online. This study compared the calculation of physicochemical characters between the SARS-Cov epitope and the SARS-Cov2 protein sequence at the same location. The characters being compared are molecular weight, point of isoelectric, aliphatic index, GRAVY, instability index, and antigenicity. Data processing is evaluated by correlation matrix. The results of the processing show that the physicochemical character between SARS-Cov and SARS-Cov2 has a strong relationship.
\end{abstract}

Intisari-Pada awal tahun 2020 dunia digemparkan dengan tersebarnya wabah secara global yang menyerang pernapasan seperti wabah SARS pada tahun 2003, yaitu COVID-19. Virus penyebab wabah yang bernama SARS-Cov 2 ini ternyata memiliki kemiripan $\sim \mathbf{8 7 . 5 \%}$ dengan SARS-Cov. Kemiripan ini dapat digunakan untuk mengembangkan obat dan vaksin yang sesuai dengan virus yang sekarang. Dalam hal ini, pendekatan secara bioinformatika dapat dilakukan sebagai tahap awal pengembangan vaksin. Salah satu cara pengembangan vaksin adalah vaksin berbasis epitope. Data biologi yang tersedia dan diserahkan kepada publik terkait epitope Sel T dan sekuen protein pada virus dapat diolah dengan beberapa tool bioinformatika yang tersedia secara online. Makalah ini membandingkan perhitungan karakter physicochemical antara epitope SARS-Cov dan sekuen protein SARS-Cov2 pada lokasi yang sama. Karakter yang dibandingkan yaitu berat molekuler, titik isoelectric, indeks alifatik, GRAVY, indeks kestabilan, dan antigenisitas. Pengolahan data dilakukan dengan matriks korelasi. Dari hasil pengolahan tersebut diketahui bahwa karakter physicochemical antara SARS-Cov dan SARS-Cov2 memiliki hubungan yang kuat.

Kata Kunci- Bioinformatika, SARS-Cov2, COVID-19, Epitope, Imunoinformatika, Biomolecular, Bio-datamining, Coronavirus.

1*,2 Teknik Informatika Fakultas Teknologi Industri Universitas Ahmad Dahlan, Jl Ring Road Selatan, Tamanan Banguntapan, Bantul, Yogyakarta, 55166 (tlp: 0274-563515; fax: 0274-564604; email: faisal.fajri@tif.uad.ac.id)

\section{PENDAHULUAN}

Dalam dua dekade terakhir ini, virus corona telah menyebabkan dua pandemi berskala besar, yaitu Severe Acute Respitatory Syndrome (SARS) dan Middle East Respitarory Syndrome (MERS). Kedua virus ini berasal dari kelelawar dan dapat menginfeksi manusia [1].

Di akhir tahun 2019 muncul varian virus corona baru yang berawal dari Wuhan, China. Persebaran virus ini sangat cepat hingga WHO mengumumkan darurat kesehatan global pada tanggal 30 Januari 2020 [2]. Virus ini dikenal dengan sebutan SARS-Cov2 dan penyakitnya disebut Coronaviruses Disease2019 (Covid-19). Kini lebih dari enam juta kasus dan 400.000 kematian telah dilaporkan dari seluruh dunia [3].

Baik SARS-Cov, MERS, maupun SARS-Cov2, ketiganya masuk dalam subfamili beta-coronavirus. Secara umum, virus ini terdiri atas rantai RNA tunggal sebagai material nukleotida dan diselimuti oleh lemak [4]. Virus ini berukuran $\sim 30 \mathrm{~kb}$ dan terbentuk dari beberapa struktur protein besar, yaitu protein surface $(\mathrm{S})$, protein envelope $(\mathrm{E})$, protein membrane $(\mathrm{M})$, dan protein nucleocapsid $(\mathrm{N})$ [5], [6].

Gbr. 1 menunjukkan pohon filogenetik yang menjelaskan hubungan 2019-nCov (SARS-Cov2) dengan virus corona lain dalam satu famili [7], sedangkan pada Tabel I diperlihatkan perbandingan kemiripan struktrur protein pada SARS-Cov2 dengan struktur protein pada SARS-Cov, Bat-Cov, dan MERSCov [8]. Ternyata SARS-Cov2 memiliki kemiripan > 90\% dengan Bat-Cov, tetapi yang menyebabkan pandemi global adalah SARS-Cov, dengan tingkat kemiripan $\sim 87.5 \%$, dan MERS-Cov dengan tingkat kemiriapan $\sim 40 \%$.

Hingga saat ini belum ditemukan vaksin yang efektif untuk mencegah dan memerangi SARS-Cov2, padahal vaksin sangat penting untuk mengurangi penyebaran virus dan memperkecil angka kematian. Salah satu cara untuk mendesain vaksin adalah dengan mempelajari epitope-nya. Epitope merupakan bagian dari protein yang dapat memicu aktifnya sistem kekebalan tubuh dan juga merupakan bagian yang dapat berikatan dengan antibodi [9].

Makalah ini bertujuan membantu proses awal desain vaksin berbasis epitope dengan menganalisis karakter pyhsicochemical-nya. Ada banyak karakter physicochemical yang dimiliki oleh protein. Dengan menganilisis karakter yang paling berpengaruh dalam pembentukan epitope, dapat dilakukan reduksi dimensi data untuk masuk dalam proses prediksi selanjutnya.

Epitope terdiri atas epitope sel T dan Epitope sel B. Sel B bertugas khusus membentuk antibodi yang sesuai, sedangkan sel $\mathrm{T}$ bertugas membunuh sel yang menghasilkan epitope. 


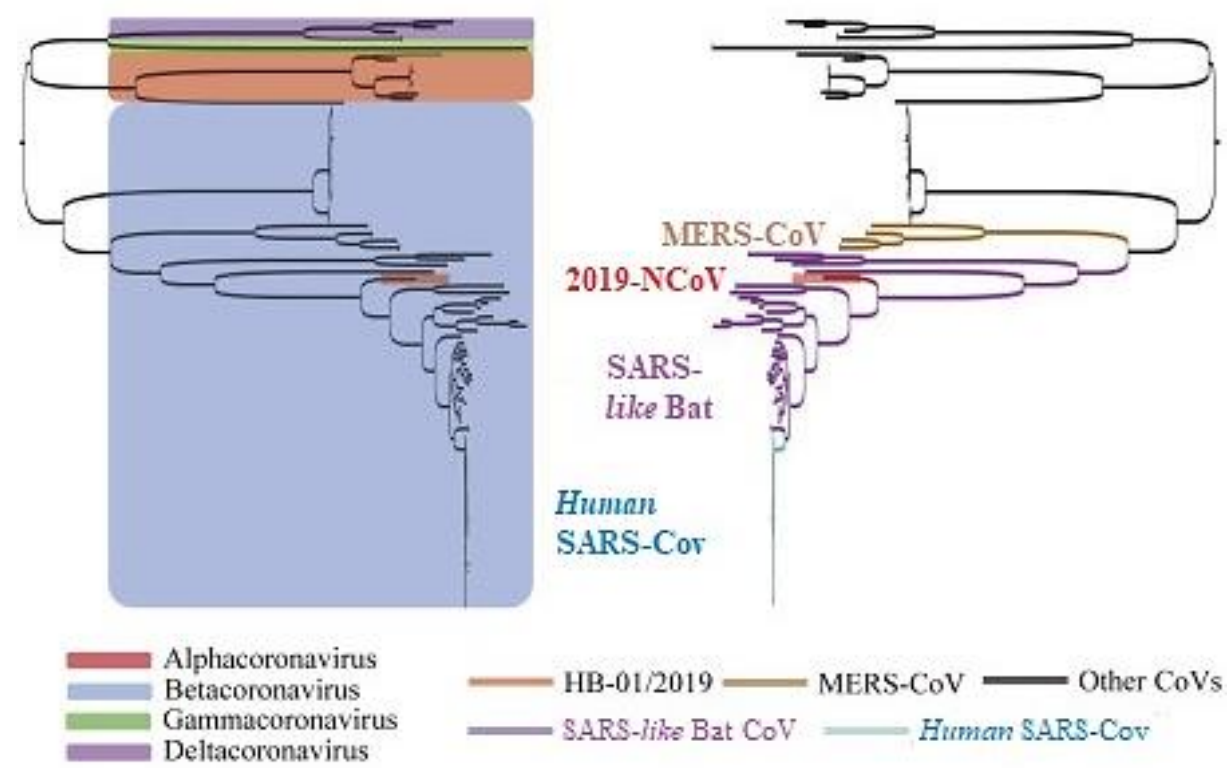

Gbr. 1 Perbandingan 2019-nCov (SARS-Cov2) dengan virus corona lain.

TABEL I

TINGKAT KEMIRIPAN STRUKTUR PROTEIN SARS-COV2 DENGAN BETACORONAVIRUS LAINNYA

\begin{tabular}{|l|c|c|c|c|}
\hline \multirow{2}{*}{ Virus } & \multicolumn{4}{|c|}{ Struktur Protein } \\
\cline { 2 - 5 } & $\mathbf{S}$ & $\mathbf{M}$ & $\mathbf{E}$ & $\mathbf{N}$ \\
\hline Bat-Cov & $80 \%$ & $98 \%$ & $100 \%$ & $94 \%$ \\
\hline SARS-Cov & $76 \%$ & $90 \%$ & $94 \%$ & $90 \%$ \\
\hline MERS-Cov & $35 \%$ & $42 \%$ & $36 \%$ & $48 \%$ \\
\hline
\end{tabular}

Berdasarkan penelitian pada SARS-Cov, diketahui bahwa sel T menyerang secara dominan pada protein $\mathrm{S}$ dan $\mathrm{N}$ [6]. Oleh karena itu, makalah ini fokus untuk menganalisis epitope sel $\mathrm{T}$ pada protein $\mathrm{S}$ dan $\mathrm{N}$.

Bioinformatika memadukan ilmu biologi molekuler, matematika, dan informatika [10]. Pendekatan dengan ilmu bioinformatika berperan untuk mengurangi waktu penelitian pada laboratorium basah biologi. Salah satu topik yang berperan dalam bidang bioinformatika adalah analisis sekuen [11]. Analisis sekuen SARS-Cov2 sangat penting mengingat virus corona dari subfamili betacoronavirus pernah menyebabkan wabah global dengan tingkat kematian yang cukup tinggi. Makalah ini mengkaji hubungan antara karakter epitope SARS-Cov dengan SARS-Cov2 dengan memanfaatkan tool bioinformatika yang dapat diakses publik di internet.

\section{DATASET}

Prediksi sekuen protein yang menjadi epitope sel T SARSCov2 diperoleh dari Immune Epitope Database (IEDB). IEDB merupakan website yang menyediakan tool untuk memprediksi epitope dengan metode komputasi [12], [13]. Dari tool ini dapat diprediksi epitope SARS-Cov2 dari epitope SARS-Cov berdasarkan kemiripannya.

Informasi yang terkumpul terkait SARS-Cov2 masih sangat sedikit dan data epitope juga belum tersedia. Meskipun demikian, informasi umum terkait virus corona seperti SARSCov dan MERS-Cov dapat diperoleh [14].
TABEL II

PERBANDINGAN JUMLAH EPITOPE SEl T PADA CoRONAVIRUS

\begin{tabular}{|c|c|c|c|c|}
\cline { 2 - 5 } \multicolumn{1}{c|}{} & SARS-Cov & MERS-Cov & Lainnya & Total \\
\hline Epitope Sel T & 164 & 25 & 54 & $\mathbf{2 4 3}$ \\
\hline
\end{tabular}

\begin{tabular}{|l|c|}
\hline \multicolumn{1}{|c|}{ Protein SARS-Cov } & Jumlah Epitope Sel T \\
\hline Surface/Spike Glycoprotein & 48 \\
\hline NucleoProtein & 33 \\
\hline Replicase Polyprotein 1ab & 9 \\
\hline Protein 3a & 7 \\
\hline Membrane Protein & 4 \\
\hline
\end{tabular}

Pada Tabel II dapat dilihat jumlah epitope sel T yang tersedia pada situs IEDB. Selain memiliki tingkat kemiripan yang tinggi dengan SARS-Cov2, ternyata SARS-Cov juga memiliki data epitope yang terbanyak. Hal ini sangat mendukung untuk memprediksi epitope SARS-Cov2 dengan pemetaan sekuen pada lokasi yang sama. Letak epitope pada masing-masing protein SARS-Cov diperlihatkan pada Tabel III [8]. Jumlah epitope pada Tabel I dan Tabel II berbeda karena pada Tabel II hanya diambil epitope SARS-Cov yang berinang pada manusia.

\section{METODOLOGI}

Metode yang dilakukan pada makalah ini ditunjukkan pada Gbr. 2. Setelah mendapatkan nilai karakteristik, masing-masing sekuen dibandingkan, kemudian diambil beberapa sekuen yang memiliki nilai antigenisitas tertinggi, lalu dilakukan molecular modeling menggunakan aplikasi PyMOL.

\section{A. Pemetaan Sekuen Epitope SARS-Cov pada SARS-Cov2}

Metode pemetaan ini dilakukan dengan membuat daftar epitope SARS-Cov dari IEDB yang paling dominan, kemudian menyimpan lokasi sekuen asam amino tersebut. Lalu, akan dibandingkan sekuen asam amino pada protein SARS-Cov2 
TABEL IV

PEMETAAN SEKUEN SARS-COV PADA SARS-Cov2

\begin{tabular}{|c|c|c|c|c|c|}
\hline $\begin{array}{c}\text { Kode } \\
\text { Sekuen }\end{array}$ & SARS-COV & SARS-Cov2 & Protein & $\begin{array}{c}\text { Pemetaan } \\
\text { Lokasi }\end{array}$ & $\begin{array}{c}\text { Kemiripan } \\
(\%)\end{array}$ \\
\hline S1 & KSFEIDKGIYQTSNFRVV & KSFTVEKGIYQTSNFRVQ & $\mathrm{S}$ & $304-321$ & 78 \\
\hline S2 & STFFSTFKCYGVSATKL & SASFSTFKCYGVSPTKL & $\mathrm{S}$ & $371-387$ & 82 \\
\hline S3 & KLPDDFMGCV & KLPDDFTGCV & $\mathrm{S}$ & $424-433$ & 90 \\
\hline S4 & KSIVAYTMSLGADSSIAY & QSIIAYTMSLGAENSVAY & $\mathrm{S}$ & $690-707$ & 72 \\
\hline S5 & SIVAYTMSL & SIIAYTMSL & $\mathrm{S}$ & $691-699$ & 89 \\
\hline S6 & TECANLLLQYGSFCTQL & TECSNLLLQYGSFCTQL & $\mathrm{S}$ & $747-763$ & 94 \\
\hline S7 & VKQMYKTPTLKYFGGGFNF & VKQIYKTPPIKDFGGFNF & $\mathrm{S}$ & $785-802$ & 78 \\
\hline S8 & ESLTTTSTALGKLQDVV & DSLSSTASALGKLQDVV & $\mathrm{S}$ & $936-952$ & 71 \\
\hline S9 & ALNTLVKQL & ALNTLVKQL & $\mathrm{S}$ & $958-966$ & 100 \\
\hline S10 & VLNDILSRL & VLNDILSR & $\mathrm{S}$ & $976-984$ & 100 \\
\hline S11 & LITGRLQSL & LITGRLQSL & $S$ & $996-1004$ & 100 \\
\hline S12 & QLIRAAEIRASANLAATK & QLIRAAEIRASANLAATK & $\mathrm{S}$ & 1011-1028 & 100 \\
\hline S13 & SWFITQRNFFSPQII & HWFVTQRNFYEPQI & S & $1101-1115$ & 73 \\
\hline S14 & RLNEVAKNL & RLNEVAKNL & $\mathrm{S}$ & $1185-1193$ & 100 \\
\hline S15 & NLNESLIDL & NLNESLIDL & $\mathrm{S}$ & $1192-1200$ & 100 \\
\hline S16 & FIAGLIAIV & FIAGLIAIV & $\mathrm{S}$ & $1220-1228$ & 100 \\
\hline M1 & GLMWLSYFV & GLMWLSYFI & $\mathrm{M}$ & $61-70$ & 89 \\
\hline M2 & TLACFVLAAV & TLACFVLAAV & M & $148-156$ & 100 \\
\hline M3 & HLRMAGHSL & HLRIAGHHL & $\mathrm{M}$ & $89-97$ & 78 \\
\hline N1 & ALNTPKDHI & ALNTPKDHI & $\mathrm{N}$ & $138-146$ & 100 \\
\hline $\mathrm{N} 2$ & LQLPQGTTL & LQLPQGTTL & $\mathrm{N}$ & $159-167$ & 100 \\
\hline N3 & GETALALLLL & GDAALALLLL & $\mathrm{N}$ & $215-224$ & 80 \\
\hline N4 & LALLLLDRL & LALLLLDRL & $\mathrm{N}$ & $219-227$ & 100 \\
\hline N5 & LLLDRLNQL & LLLDRLNQL & $\mathrm{N}$ & $222-230$ & 100 \\
\hline N6 & RLNQLESKV & RLNQLESKM & $\mathrm{N}$ & $226-234$ & 89 \\
\hline N7 & TKQYNVTQAF & TKAYNVTQAF & $\mathrm{N}$ & $265-274$ & 90 \\
\hline N8 & GMSRIGMEV & GMSRIGMEV & $\mathrm{N}$ & $316-324$ & 100 \\
\hline N9 & MEVTPSGTWL & MEVTPSGTWL & $\mathrm{N}$ & $322-331$ & 100 \\
\hline N10 & QFKDNVILL & NFKDQVILL & $\mathrm{N}$ & $345-353$ & 78 \\
\hline
\end{tabular}

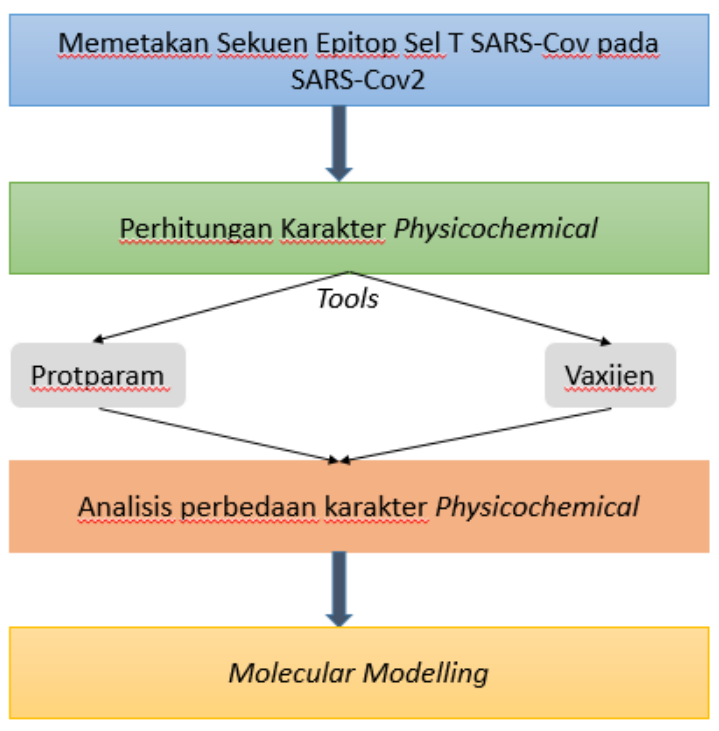

Gbr. 2 Metode analisis epitope sel T.

pada lokasi yang sama. Metode ini pernah dilakukan dan berhasil memetakan 48 sekuen epitope SARS-Cov ke SARSCov2 [8]. Pada makalah ini dipilih 29 epitope yang memiliki tingkat kemiripan lebih dari $70 \%$. Hasil pemetaan sekuen epitope SARS-Cov pada SARS-Cov2 disajikan pada Tabel IV.

\begin{tabular}{rc|}
\hline Posisi & \multicolumn{2}{|c|}{300} \\
Sars-Cov & NPLAEL KCSVKSFEIDKGIYOTSNFRVVPSGDVVRFPNIT \\
Sars-Cov2 & DPLSETKCTLKSETVEKGIYOTSNFRVOPTESIVRFPNIT \\
\hline
\end{tabular}

Gbr. 3 Pemetaan lokasi epitope pada lokasi 304-321.

Contoh pemetaan lokasi epitope sel T SARS-Cov pada SARSCov2 ditunjukkan pada Gbr. 3.

\section{B. Perhitungan Karakteristik Physicochemical}

Protein yang menyusun organisme (virus, bakteri, tumbuhan, hewan) terbuat dari dua puluh asam amino [15]. Setiap asam amino memiliki karakteristik physicochemical yang menjelaskan ciri fisik dan kimianya. Beberapa karakteristik tersebut yaitu berat molekuler, antigenisitas, hydrophilicity, hydrophobicity, indeks alifatik, indeks kestabilan, dan titik isoelectric. Berat molekul berarti berat molekuler suatu protein. Antigenisitas atau reaktivitas antigenik mengacu pada kapasitas virus untuk mengikat molekul antibodi tertentu [16]. Hydrophilicity merupakan sifat molekul yang dapat berikatan dengan air, sedangkan hydrophobicity merupakan sifat molekul yang takut/tidak dapat berikatan dengan air. Indeks alifatik merupakan volume relatif yang ditempati oleh rantai samping alifatik seperti alanine, 
TABEL V

HASIL PERHITUNGAN PHYSICOCHEMICAL

\begin{tabular}{|c|c|c|c|c|c|c|c|c|c|c|c|c|}
\hline \multirow[t]{2}{*}{ Kode } & \multicolumn{2}{|c|}{$\begin{array}{c}\text { Berat Molekul } \\
\text { (BM) }\end{array}$} & \multicolumn{2}{|c|}{$\begin{array}{c}\text { Titik Isoelectric } \\
\text { (TI) }\end{array}$} & \multicolumn{2}{|c|}{$\begin{array}{l}\text { Indeks Alifatik } \\
\text { (IA) }\end{array}$} & \multicolumn{2}{|c|}{$\begin{array}{l}\text { GRAVY } \\
\text { (GRA) }\end{array}$} & \multicolumn{2}{|c|}{$\begin{array}{l}\text { Indeks Kestabilan } \\
\text { (IK) }\end{array}$} & \multicolumn{2}{|c|}{$\begin{array}{l}\text { Antigenisitas } \\
\text { (Ant) }\end{array}$} \\
\hline & SARS & SARS-2 & SARS & SARS-2 & SARS & SARS-2 & SARS & SARS-2 & SARS & SARS-2 & SARS & SARS-2 \\
\hline S1 & $2.131,42$ & $2.132,40$ & 8,5 & 9,70 & 75,56 & 53,89 & $-0,406$ & $-0,694$ & $-2,36$ & $-8,34$ & 0,3829 & 0,3790 \\
\hline $\mathrm{S} 2$ & $1.887,18$ & $1.823,09$ & 9,19 & 9,90 & 45,88 & 45,88 & 0,394 & 0,129 & 5,10 & 23,69 & 0,6165 & 0,8820 \\
\hline S3 & $1.124,34$ & $1.094,25$ & 4,21 & 4,21 & 68,00 & 68,00 & 0,230 & $-0,030$ & $-2,85$ & $-11,34$ & $-0,4911$ & $-0,5308$ \\
\hline S4 & $1.877,14$ & $1.918,15$ & 5,83 & 4,00 & 97,78 & 97,78 & 0,556 & 0,428 & 36,39 & 48,83 & 0,3717 & 0,4592 \\
\hline S5 & 984,18 & 998,20 & 5,24 & 5,24 & 130,00 & 141,11 & 1,400 & 1,433 & 38,84 & 48,28 & 0,6198 & 0,5234 \\
\hline S6 & $1.904,18$ & $1.920,18$ & 4,00 & 4,00 & 97,65 & 91,76 & 0,406 & 0,253 & 71,08 & 71,08 & 0,7436 & 0,6982 \\
\hline S7 & $2.226,62$ & $2.099,46$ & 9,83 & 9,53 & 35,79 & 59,44 & $-0,379$ & $-0,367$ & 33,49 & 21,30 & $-0,0029$ & 0,1499 \\
\hline S8 & $1.762,98$ & $1.690,87$ & 4,37 & 4,21 & 108,82 & 114,71 & 0,141 & 0,276 & 41,26 & 52,59 & 0,7630 & 0,6237 \\
\hline S9 & 999,22 & 999,22 & 8,80 & 8,80 & 173,33 & 173,33 & 0,644 & 0,644 & 22,57 & 22,57 & $-0,5716$ & $-0,5716$ \\
\hline S10 & $1.042,24$ & 929,08 & 5,81 & 5,81 & 205,56 & 182,50 & 0,867 & 0,500 & 51,69 & 56,90 & $-0,8524$ & $-0,8576$ \\
\hline S11 & $1.000,21$ & $1.000,21$ & 9,75 & 9,75 & 173,33 & 173,33 & 0,667 & 0,667 & 84,50 & 84,50 & 0,8238 & 0,8238 \\
\hline S12 & $1.897,21$ & $1.897,21$ & 10,84 & 10,84 & 120,00 & 120,00 & 0,130 & 0,139 & 20,14 & 20,14 & 0,3527 & 0,3527 \\
\hline S13 & $1.884,17$ & $1.865,08$ & 9,47 & 6,75 & 78,00 & 48,57 & 0,140 & $-0,850$ & 44,65 & 39,27 & 3 & 0,4830 \\
\hline S14 & $1.056,23$ & $1.056,23$ & 8,75 & 8,75 & 130,00 & 130,00 & $-0,589$ & $-0,589$ & 8,89 & 8,89 & 0,1820 & 0,1820 \\
\hline S15 & $1.030,14$ & $1.030,14$ & 3,67 & 3,67 & 173,33 & 173,33 & 0,122 & 0,122 & 30,29 & 30,29 & 0,6827 & 0,6827 \\
\hline S16 & 916,17 & 916,17 & 5,52 & 5,52 & 227,78 & 227,78 & 3.056 & 3,056 & $-0,54$ & $-0,54$ & 0,3162 & 0,3162 \\
\hline M1 & $1.115,36$ & $1.129,38$ & 5,52 & 5,52 & 118,89 & 130,00 & 1.456 & 1,489 & 22,60 & 22,60 & 0,2548 & 0,2537 \\
\hline M2 & $1.007,26$ & $1.007,26$ & 5,18 & 5,18 & 166,00 & 166,00 & 2,600 & 2,600 & 52,94 & 52,94 & 1,2318 & 1,2318 \\
\hline M3 & $1.021,21$ & $1.053,23$ & 9,76 & 9,77 & 97,78 & 141,11 & $-0,089$ & $-0,067$ & 44,00 & 30,29 & 0,4547 & 0,2446 \\
\hline N1 & $1.008,14$ & $1.008,14$ & 6,79 & 6,79 & 97,78 & 97,78 & $-0,700$ & $-0,700$ & 48,28 & 48,28 & $-0,8423$ & $-0,8423$ \\
\hline $\mathrm{N} 2$ & 970,13 & 970,13 & 5,52 & 5,52 & 130,00 & 130,00 & 0,111 & 0,110 & 78,48 & 78,48 & 0,0480 & 0,0480 \\
\hline N3 & $1.013,24$ & $1.013,24$ & 4,00 & 4,00 & 215,00 & 215,00 & 1,800 & 1,800 & 1,46 & 1,46 & 0,5482 & 0,5482 \\
\hline N4 & $1.039,33$ & $1.039,33$ & 5,84 & 5,84 & 271,11 & 271,11 & 1,844 & 1,844 & 0,51 & 0,51 & 0,5933 & 0,5933 \\
\hline N5 & $1.097,32$ & $1.097,32$ & 5,84 & 5,84 & 216,67 & 216,67 & 0,444 & 0,444 & $-7,87$ & $-7,87$ & 0,1566 & 0,1566 \\
\hline N6 & $1.086,26$ & $1.118,32$ & 8,75 & 8,75 & 118,89 & 86,67 & $-0,878$ & $-1,133$ & 12,48 & 58,13 & 0,3912 & 0,5632 \\
\hline N7 & $1.199,33$ & 1142,00 & 8,26 & 8,26 & 39,00 & 49,00 & $-0,830$ & $-0,300$ & 9,11 & $-7,03$ & 0,3666 & 0,4932 \\
\hline N8 & 979,18 & 979,18 & 6,00 & 6,00 & 75,56 & 75,56 & 0,322 & 0,322 & 79,11 & 79,11 & 0,6287 & 0,6287 \\
\hline N9 & $1.120,29$ & $1.120,29$ & 4,00 & 4,00 & 68,00 & 68,00 & 0,130 & 0,130 & 8,59 & 8,59 & 0,6342 & 0,6342 \\
\hline N10 & $1.089,30$ & $1.089,30$ & 5,84 & 5,84 & 162,22 & 162,22 & 0,522 & 0,522 & 5,21 & $-11,49$ & 0,5844 & 1,1677 \\
\hline
\end{tabular}

valine, isoluesin, dan leusin. Indeks kestabilan adalah perkiraan kestabilan protein dalam suatu tabung uji [17]. Yang terakhir, titik isoelectric merupakan $\mathrm{pH}$ larutan ketika muatan bersih protein menjadi nol [18] .

Perhitungan ini dilakukan menggunakan tool bioinformatika yang tersedia online di internet, yaitu Protparam dan VaxiJen. Dalam mendesain sebuah obat dan vaksin, beberapa karakteristik physicochemical yang digunakan antara lain berat molekuler, jumlah residu positif dan negatif, indeks kestabilan, indeks alifatik, Grand Average of Hydropathicity (GRAVY), titik isoelectric, antigenisitas, dan hydrophilicity [19]. Hidropathicity merupakan angka relatif yang mencerminkan hydrophilicity dan hydrophobicity [20].

Perhitungan physicochemical terkait berat molekuler, titik isoelectric, indeks kestabilan, indeks alifatik, dan GRAVY dilakukan menggunakan tool Protparam [17], sedangkan perhitungan antigenisitas dilakukan menggunakan tool VaxiJen [21]. Hasil perhitungan karakteristik physicochemical diperlihatkan pada Tabel V.

\section{Analisis Perbedaan Karakter}

Analisis karakter SARS-Cov dan SARS-Cov2 dilakukan menggunakan metode statistik dasar dan matrik korelasi. Setiap karakter dihitung rata-rata dan standar deviasinya, mengacu pada (1) dan (2). Kemudian, seluruh karakteristik dihitung korelasinya dengan matriks korelasi berdasarkan teori Pearson mengacu pada (3). Matriks korelasi memiliki rentang antara -1 hingga 1 . Nilai -1 untuk relasi yang sangat lemah, sedangkan nilai 1 untuk relasi yang sangat kuat [22].

$$
\begin{gathered}
\bar{x}=\frac{x_{1}+x_{2}+\cdots+x_{n}}{n} \\
s=\sqrt{\frac{n \sum_{i=1}^{n} x_{1}^{2}-\left(\sum_{i=1}^{n} x_{1}^{2}\right)^{2}}{n(n-1)}} \\
r=\frac{n\left(\sum x y\right)-\left(\sum x\right)-\left(\sum y\right)}{\sqrt{\left[\sum x^{2}-\left(\sum x\right)^{2}\right]\left[\sum y^{2}-\left(\sum y\right)^{2}\right]}}
\end{gathered}
$$

\section{Molecular Modeling}

Visualisasi daerah epitope pada protein SARS-Cov2 dilakukan menggunakan software Pymol. Data protein SARS yang digunakan berasal dari Protein Data Bank (PDB) dengan ID 6VSB [23], [24]. Pada proses visualisasi ini hanya ditampilkan epitope pada protein $\mathrm{S}$, karena pemodelan molekul protein $\mathrm{M}$ dan $\mathrm{N}$ untuk SARS-Cov2 dengan sekuen yang lengkap belum tersedia.

Pada Gbr. 4 diperlihatkan pemodelan molekuler lokasi epitope dengan PDB ID=6VSB. Daerah yang berwarna merah adalah lokasi epitope pada S2, S6, S8, dan S11, yaitu sekuen 


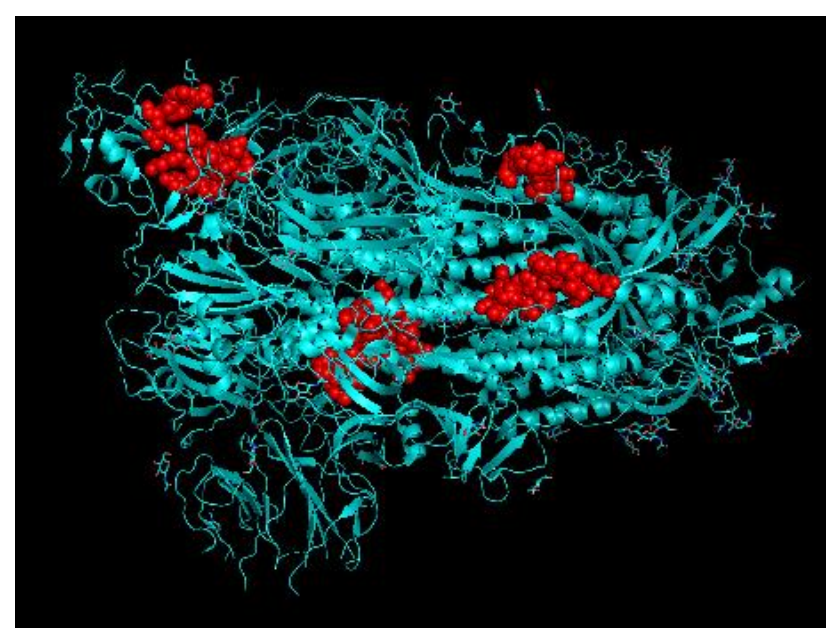

Gbr. 4 Pemodelan molekuler lokasi epitope.

'SASFSTFKCYGVSPTKL', 'TECSNLLLQYGSFCTQL', 'DSLSSTASALGKLQDVV', dan 'LITGRLQSL'. Empat lokasi yang dipilih merupakan lokasi dengan nilai antigenisitas tertinggi.

\section{HASIL DAN PEMBAHASAN}

Pada Tabel VI dapat dilihat hasil perhitungan rata-rata untuk seluruh karakteristik pada SARS-Cov dan SARS-Cov2. Hasil rata-rata untuk indeks alifatik dan antigenisitas lebih besar pada SARS-Cov2 daripada SARS-Cov, sedangkan pada karakter lainnya, rata-rata SARS-Cov2 lebih kecil daripada SARS-Cov.

Dapat dikatakan bahwa epitope SARS-Cov2 memiliki rantai samping alifatik dan antigenisitas lebih besar daripada epitope SARS-Cov, tetapi berat molekulnya lebih ringan dan kestabilannya lebih kecil. Dari hasil ini, dapat diketahui bahwa epitope sel T SARS-Cov2 lebih mudah berikatan dengan antibodi, tetapi kurang stabil.

Hasil perhitungan standar deviasi disajikan pada Tabel VII. Standar deviasi berat molekul dan GRAVY pada SARS-Cov2 lebih kecil, sedangkan karakter lainnya lebih besar. Dari ratarata dan standar deviasi, dapat dikatakan bahwa karakteristik sekuen protein pada epitope sel T SARS-Cov maupun SARSCov2 memiliki kemiripan $>90 \%$. Padahal pemetaan sekuen dipilih dengan nilai kemiripan $>70 \%$, sehingga perubahan asam amino terjadi dengan asam amino lain yang memiliki karakter berdekatan.

Kemudian pada Tabel VIII dapat dilihat matriks korelasi antar karakter SARS-Cov dan SARS-Cov2. Warna biru menunjukkan adanya relasi yang sangat kuat, warna oranye menunjukkan relasi yang kuat, warna hijau menunjukkan relasi yang cukup kuat, warna abu-abu menunjukkan lemah, sedangkan yang tidak berwarna menunjukkan relasi yang sangat lemah, bahkan tidak ada relasi. Terlihat bahwa pada karakter yang sama terdapat relasi yang sangat kuat antara SARS-Cov dan SARS-Cov2. Lalu, relasi yang kuat terjadi antara karakter kestabilan dan GRAVY, relasi lemah ditunjukkan antara karakter antigenisitas dengan kestabilan, sedangkan karakter yang tidak memiliki relasi yang kuat dengan karakter lain adalah karakter indeks alifatik.
TABEL VI

HASIL PERHITUNGAN RATA-RATA

\begin{tabular}{|l|c|c|c|c|c|c|}
\cline { 2 - 7 } \multicolumn{1}{c|}{} & \multicolumn{7}{c|}{ Rata-Rata } \\
\cline { 2 - 7 } \multicolumn{1}{c|}{} & BM & TI & IK & GRA & IK & Ant \\
\hline Cov & $1.292,01$ & 6,72 & 28,89 & 128,19 & 0,487 & 0,333 \\
\hline Cov2 & $1.280,60$ & 6,62 & 29,73 & 127,95 & 0,419 & 0,356 \\
\hline
\end{tabular}

TABEL VII

HASIL PERHITUNGAN STANDAR DEVIASI

\begin{tabular}{|l|c|c|c|c|c|c|}
\cline { 2 - 7 } \multicolumn{1}{c|}{} & \multicolumn{6}{c|}{ Standar Deviasi } \\
\cline { 2 - 7 } \multicolumn{1}{c|}{} & BM & TI & IK & GRA & IK & Ant \\
\hline Cov & 421,67 & 2,18 & 27,16 & 60,74 & 0,95 & 0,489 \\
\hline Cov2 & 410,56 & 2,25 & 29,66 & 60,50 & 0,99 & 0,513 \\
\hline
\end{tabular}

TABEL VIII

MATRIKS KORELASI

\begin{tabular}{|l|c|c|r|r|r|r|}
\hline & BM & TI & \multicolumn{1}{c|}{ IK } & GRA & IK & \multicolumn{1}{c|}{ Ant } \\
\hline BM & 0,996 & 0,269 & $-0,027$ & $-0,568$ & $-0,389$ & 0,153 \\
\hline TI & 0,336 & 0,955 & 0,001 & $-0,293$ & $-0,444$ & $-0,071$ \\
\hline IK & $-0,031$ & $-0,059$ & 0,919 & $-0,122$ & $-0,063$ & 0,013 \\
\hline GRA & $-0,532$ & $-0,265$ & $-0,097$ & 0,972 & 0,642 & $-0,014$ \\
\hline IK & $-0,315$ & $-0,410$ & $-0,054$ & 0,665 & 0,970 & 0,229 \\
\hline Ant & 0,087 & $-0,140$ & 0,159 & 0,062 & 0,276 & 0,961 \\
\hline
\end{tabular}

Pertimbangan bahwa karakter epitope SARS-Cov2 lebih ringan, lebih mudah berikatan dengan antibodi, dan kurang stabil dapat membantu proses pembuatan vaksin berbasis epitope. Karakter-karakter tersebut nantinya akan berpengaruh pada desain struktur protein yang akan direspons oleh antibodi.

\section{KESIMPULAN DAN SARAN}

Pemetaan epitope SARS-Cov pada SARS-Cov2 sebagai tahap awal pembuatan desain vaksin dapat dipertimbangkan, karena adanya relasi yang kuat antara karakter physicochemical SARS-Cov dan SARS-Cov2. Adanya perubahan asam amino akibat mutasi tidak berdampak signifikan pada epitope penelitian kali ini. Dari karakter yang telah diteliti ternyata indeks alifatik tidak memberikan perbedaan yang signifikan, sehingga karakter tersebut dapat dihilangkan pada penelitian selanjutnya. Penelitian selanjutnya dapat membandingkan lokasi epitope SARS-Cov dengan SARS-Cov2 yang khusus berasal dari Indonesia dengan bantuan mesin pembelajaran karena keberagaman genom yang sangat tinggi.

\section{UCAPAN TERIMA KASIH}

Ucapan terima kasih disampaikan kepada Ilmu Komputer UGM yang telah memberikan dasar ilmu Bioinformatika, kemudian kepada Magister Teknologi Informasi UGM yang telah mengajarkan metode analisis yang dalam, dan terakhir disampaikan kepada UAD yang terus menyemangati untuk terus melanjutkan penelitian.

\section{REFERENSI}

[1] P. Zhou, X.-L. Yang, X.-G. Wang, B. Hu, L. Zhang, dkk., “A Pneumonia Outbreak Associated with a New Coronavirus of Probable Bat Origin," Nature, Vol. 579, No. 7798, hal. 270-273, 2020.

[2] (2020) "BBC News" [Online], https://www.bbc.com/news/world51318246, tanggal akses: 9-Jun-2020.

[3] (2020) "WHO Coronaviruses Disease Dashboard" [Online], https://covid19.who.int/, tanggal akses: 9-Jun-2020. 
[4] M.A. Shereen, S. Khan, A. Kazmi, N. Bashir, dan R. Siddique, "COVID19 Infection: Origin, Transmission, and Characteristics of Human Coronaviruses," J. Adv. Res., Vol. 24, hal. 91-98, 2020.

[5] R.A. Khailany, M. Safdar, dan M. Ozaslan, "Genomic Characterization of a Novel SARS-CoV-2," Gene Reports, Vol. 19, hal. 1-6, 2020.

[6] S.F. Ahmed, A.A. Quadeer, dan M.R. McKay, "Preliminary Identification of Potential Vaccine Targets for the COVID-19 Coronavirus (SARS-CoV-2) Based on SARS-CoV Immunological Studies," Viruses, Vol. 12, No. 3, hal. 1-15, 2020.

[7] A. Wu, Y. Peng, B. Huang, X. Ding, X. Wang, P. Niu, J. Meng, Z. Zhu, Z. Zhang, J. Wang, J. Sheng, L. Quan, Z. Xia, W. Tan, G. Cheng, dan T. Jiang, "Genome Composition and Divergence of the Novel Coronavirus (2019-nCoV) Originating in China," Cell Host Microbe, Vol. 27, No. 3, hal. 325-328, 2020.

[8] A. Grifoni, J. Sidney, Y. Zhang, R.H. Scheuermann, B. Peters, dan A Sette, "A Sequence Homology and Bioinformatic Approach can Predict Candidate Targets for Immune Responses to SARS-CoV-2," Cell Host Microbe, Vol. 27, No. 4, hal. 671-680.e2, 2020.

[9] R. Kogay dan C. Schönbach, "Epitope Predictions," Encycl. Bioinforma. Comput. Biol.: ABC Bioinforma., Vol. 2, No. 1, hal. 952-971, 2018.

[10] D.A. Aprijani dan M.A. Elfaizi, "BIOINFORMATIKA: Perkembangan, Disiplin Ilmu dan Penerapannya di Indonesia," Universitas Gunadarma, Jakarta, Indonesia, Kuliah, hal. 1-25, 2004.

[11] I.Y. Abdurakhmonov, "Bioinformatics: Basics, Development, and Future," dalam Bioinformatics - Updated Features and Applications, I.Y. Abdurakhmonov, Ed., London, UK: IntechOpen, 2016.

[12] S.K. Dhanda, S. Mahajan, S. Paul, Z. Yan, H. Kim, M.C. Jespersen, V. Jurtz, M. Andreatta, J. A. Greenbaum, P. Marcatili, A. Sette, M. Nielsen, dan B. Peters, "IEDB-AR: Immune Epitope Database - Analysis Resource in 2019," Nucleic Acids Res., Vol. 47, No. W1, hal. W502W506, 2019.

[13] Y. Kim, A. Sette, dan B. Peters, “Applications for T-cell Epitope Queries and Tools in the Immune Epitope Database and Analysis Resource," $J$. Immunol. Methods, Vol. 374, No. 1-2, hal. 62-69, 2011.

[14] Z. Song, Y. Xu, L. Bao, L. Zhang, P. Yu, Y. Qu, H. Zhu, W. Zhao, Y. Han, dan C. Qin, "From SARS to MERS, Thrusting Coronaviruses into the Spotlight," Viruses, Vol. 11, No. 1, hal. 1-28, 2019.

[15] A.J. Cozzone, "Proteins: Fundamental Chemical Properties," Encycl. Life Sci., hal. 1-10, 2010.

[16] M.H.V Van Regenmortel, "Antigenicity and Immunogenicity of Viral Proteins," dalam Encyclopedia of Virology, $3^{\text {rd }}$ ed., B.W.J. Mahy dan M.H.V. Van Regenmortel, Eds., Cambridge, USA: Academic Press, hal. 137-142, 2008, hal. 137-142.

[17] E. Gasteiger, C. Hoogland, A. Gattiker, S. Duvaud, R. Appel, dan A Bairoch, "Protein Identification and Analysis Tools on the ExPASy Server," dalam The Proteomics Protocols Handbook, 1st ed., W.M. John, Ed., Totowa, USA: Humana Press, hal. 571-607, 2005.

[18] P. Novák dan V. Havlíček, "Protein Extraction and Precipitation," dalam Proteomic Profiling and Analytical Chemistry, $2^{\text {nd }}$ ed., P. Ciborowski dan J. Silberring, Eds., New York, USA: Elsevier, 2016, hal. 51-62.

[19] S. Kumar, "Drug and Vaccine Design against Novel Coronavirus (2019nCoV) Spike Protein through Computational Approach," Preprints, hal 1-16, Feb. 2020

[20] J. Kyte dan R.F. Doolittle, "A Simple Method for Displaying the Hydropathic Character of a Protein," J. Mol. Biol., Vol. 157, No. 1, hal 105-132, 1982.

[21] I.A. Doytchinova dan D.R. Flower, "Identifying Candidate Subuni Vaccines Using an Alignment-Independent Method Based on Principal Amino Acid Properties," Vaccine, Vol. 25, No. 5, hal. 856-866, 2007.

[22] A.P. King dan R.J. Eckersley, "Descriptive Statistics II: Bivariate and Multivariate Statistics," dalam Statistics for Biomedical Engineers and Scientists, Cambridge, USA: Academic Press, hal. 23-56, 2019.

[23] H.M. Berman, J. Westbrook, Z. Feng, G. Gilliland, dkk., "The Protein Data Bank," Acta Crystallogr. Sect. D Biol. Crystallogr., Vol. 58, No. 6I, hal. 899-907, 2002.

[24] D. Wrapp, N. Wang, K. Corbett, J.A. Goldsmith, C. Hsieh, O. Abiona, B S. Graham, dan J.S. Mclellan, "Cryo-EM Structure of the 2019-nCoV Spike in the Prefusion Conformation," Science, Vol. 367, No. 6483, hal 1260-1263, Mar. 2020. 